J. Clin. Chem. Clin. Biochem.

Vol. 24, 1986, pp. 387-392

(C) 1986 Walter de Gruyter \& Co. Berlin - New York

\title{
Evaluation of the Spectrophotometric Assay of Guanase with 2,2'-Azino-di(3-ethylbenzthiazoline-6-sulphonate) (ABTS) as Chromogen
}

\author{
By Nada Majkić-Singh, Dušica Popović and Slavica Spasić \\ Department of Biochemistry, Faculty of Pharmacy, Belgrade, Yugoslavia
}

(Received August 5, 1985/January 13, 1986)

Summary: A simple spectrophotometric assay for serum guanase based on the oxidation of $2,2^{2}$-azino-di(3ethylbenzthiazoline-6-sulphate) (ABTS) using xanthine oxidase, uricase and peroxidase is described and statistically examined through its application to normal and pathological sera. The method is very sensitive, precise (CV below 8.13\%) and linear up to $152.5 \mathrm{U} / 1$. Comparison with the methods of Hue \& Free ((1965) Clin. Chem. 11, 708-715), and Giusti ((1974) In: Methods of Enzymatic Analysis, Bergmeyer, H. U., ed., p. 1086), and Ito et al. ((1981) Clin. Chim. Acta 115, 135-144) gave a good correlation ( $\mathrm{r} \geqslant 0.969)$. The reference values for the ABTS-method are 2.93 to $23.92 \mathrm{U} / 1(\overline{\mathrm{x}}=13.57 \mathrm{U} / 1, \mathrm{CV}=22.43 \%)$. The mean values of guanase activities determined in sera of patients with different liver diseases $(\overline{\mathrm{x}}=30.29 \mathrm{U} / \mathrm{l})$, or chronic alcoholics $(\overline{\mathrm{x}}=35.41 \mathrm{U} / \mathrm{l})$ were significantly higher than normal. The patients with chronic diseases had significantly lower activity $(\overline{\mathrm{x}}=7.22 \mathrm{U} / \mathrm{l}, \mathrm{t}=9.25, \mathrm{p}<0.001)$.

Evaluation der spektrophotometrischen Bestimmung von Guanase mit 2,2'-Azino-di(3-ethylbenzthiazol-6-sulfonat) als Chromogen

Zusammenfassung: Eine einfache spektrophotometrische Bestimmung für Guanase im Serum auf Grundlage der Oxidation von 2,2'-Azino-di(3-ethylbenzthiazol-6-sulfonat) (ABTS) mit Xanthinoxydase, Uricase und Peroxidase wird beschrieben und hinsichtlich ihrer Anwendung auf normale und pathologische Seren untersucht. Die Methode ist sebr empfindlich, genau (VK unter 8,13\%) und linear bis 152,5 U/1. Ein Vergleich mit den Methoden von Hue \& Free ((1965) Clin. Chem. 11, 708-715) sowie Giusti ((1974) In: Methods of Enzymatic Analysis, Bergmeyer, H. U., ed., p. 1086) und Ito et al. ((1981) Clin. Chim. Acta 115, 135-144) ergaben eine gute Korrelation $(r \geqslant 0,969)$. Die Referenzwerte für die ABTS-Methode sind 2,93 bis 23,92 U/1 $(\overline{\mathrm{x}}=13,57 \mathrm{U} / 1, \mathrm{VK}=22,43 \%)$. Die Mittelwerte der katalytischen Konzentration von Guanase im Serum von Patienten mit verschiedenen Lebererkrankungen $(\overline{\mathrm{x}}=30,29 \mathrm{U} / 1)$, oder chronischen Alkoholikern $(\overline{\mathrm{x}}=$ 35,41 U/1) waren signifikant höher als normal. Die Patienten mit chronischen Erkrankungen zeigten eine signifikant niedrigere katalytische Konzentration $(\overline{\mathrm{x}}=7,22 \mathrm{U} / \mathrm{l}, \mathrm{t}=9,25, \mathrm{p}<0,001)$.

\section{Introduction}

Guanine deaminase (guanase, guanine aminohydrolase, EC 3.5.4.3) plays an important role in the catabolism of purines. Guanase catalyses the hydrolytic deamination of guanine into xanthine and ammonia. The enzyme is present in many animal and human tissues $(1,2)$. In humans, high activities have been found in liver, kidney and brain, and little or no activity in other organs $(2,3)$.
Many methods have been used for guanase assay. They are based either on measurements of the decrease in absorbance at $245 \mathrm{~nm}$ (4), or measurement of the ammonia formed by guanase action (5-7). If xanthine is oxidized by xanthine oxidase (xanthine: oxygen oxidoreductase, EC 1.2.3.2), guanase catalytic activity can be measured via uric acid $(8,9)$ or $\mathrm{H}_{2} \mathrm{O}_{2}$ formed in this reaction $(10,11) ; \mathrm{O}_{2}$ consumption also can be measured (12). A more sensitive radiochemical 
assay has also been described, based on the measurement of the radioactive uric acid produced upon incubation with radioactive guanine and excess xanthine oxidase $(13,14)$.

In the present guanase assay we used the chromogen, 2,2'-azino-di(3-ethylbenzthiazoline-6-sulphonate)

(ABTS), which is stoichiometrically oxidized in the following system of coupled reactions:

$$
\begin{aligned}
& \text { Guanine }+\mathrm{H}_{2} \mathrm{O} \stackrel{\text { Guanase }}{\longrightarrow} \text { Xanthine }+\mathrm{NH}_{3}
\end{aligned}
$$

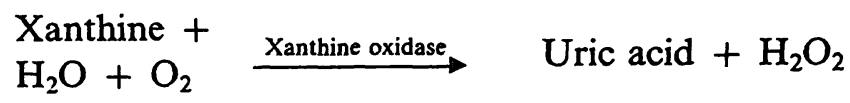

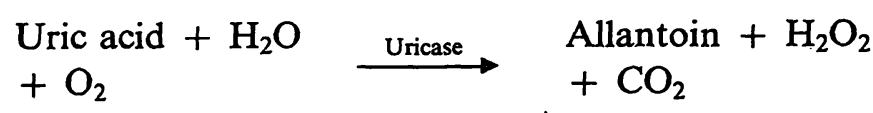

$$
\begin{aligned}
& \mathrm{H}_{2} \mathrm{O}_{2}+\mathrm{ABTS}_{\mathrm{red}} \stackrel{\text { Peroxidase }}{\longrightarrow} \mathrm{ABTS}_{\mathrm{ox}}+2 \mathrm{H}_{2} \mathrm{O}
\end{aligned}
$$

The absorbance of oxidized ABTS recorded at 410 $\mathrm{nm}$ is directly proportional to guanase activity in the sample.

The method was statistically evaluated. Reference values were determined, and the method was applied to different pathological sera.

\section{Materials and Methods}

\section{Chemicals}

The diammonium salt of 2,2'-azino-di(3-ethylbenzthiazoline-6sulphonate) cryst., guanase from rabbit liver, suspension in ammonium sulphate solution, $3.3 \mathrm{~mol} / \mathrm{l}, \mathrm{pH}$ ca. 6 , spec. activity $60 \mathrm{U} / \mathrm{g}$ and horseradish peroxidase, spec. activity $250 \mathrm{U} / \mathrm{mg}$ were purchased from Boehringer-Mannheim, FRG. Guanine, xanthine oxidase (bovine milk), crystalline suspension in 3.3 $\mathrm{mol} / \mathrm{l}$ ammonium sulphate, spec. activity $2.65 \mathrm{kU} / \mathrm{l}$ were from Calbiochem-Behring Corp. Uricase from porcine liver, ca. 10 $\mathrm{U} / \mathrm{mg}$ in $50 \%$ glycerol $\mathrm{pH} 9.3(1.6 \mathrm{~g} / \mathrm{l})$ was obtained from Serva, Heidelberg, FRG. Sodium azide puriss was obtained from Koch-Light Laboratories, LTD, England. All other chemicals of analytical grade were from Merck-Darmstadt, FRG. All solutions were prepared with doubly distilled water.

\section{Biological materials}

The investigations were carried on different human (normal and pathological) sera, serum pools and control sera Kontrollogen L, Lu and LP obtained from Behringwerke, Marburg, FRG. Serum samples are kept at $-20^{\circ} \mathrm{C}$ before analysing guanase catalytic activity.

\section{Solutions}

\section{Substrate-buffer solution}

This solution contains $100 \mu \mathrm{mol}$ guanine, $26.5 \mathrm{U}$ xanthine oxidase, $76.19 \mathrm{U}$ uricase and $20 \mathrm{mmol}$ sodium azide in $1000 \mathrm{ml}$ of $66.7 \mathrm{mmol} / \mathrm{l}$ phosphate buffer, $\mathrm{pH} 7.0$. It is stable 30 minutes at room temperature and should be prepared before use. Otherwise xanthine oxidase and uricase must be pipetted separately.

\section{Reagent solution}

Based on the determination of optimal conditions, a reagent with the following composition was made: $4.55 \mathrm{mmol}$ ABTS and $2500 \mathrm{U}$ peroxidase in $1000 \mathrm{ml}$ of $66.7 \mathrm{mmol} / 1$ phosphate buffer, pH 7.0. This solution is stable more than two months.

\section{Spectrophotometric assay of guanase}

The new spectrophotometric method for guanase is based on oxidation of chromogen ABTS through the system of coupled reactions catalysed by xanthine oxidase, uricase and peroxidase. To optimize this assay, the conditions characterizing this multiple reaction system were studied. $K_{\mathrm{m}}$ for guanine as substrate is $7.54 \mu \mathrm{mol} / \mathrm{l}$. The maximal guanase activity measured at $37^{\circ} \mathrm{C}$ was obtained with $95.23 \mu \mathrm{mol} / 1$ guanine, $25.23 \mathrm{U} / \mathrm{l}$ xantbine oxidase, $76.19 \mathrm{U} / \mathrm{l}$ uricase, $819.6 \mathrm{U} / 1$ peroxidase and 1.49 $\mathrm{mmol} / \mathrm{l}$ of ABTS in $66.7 \mathrm{mmol} / \mathrm{l}$ phosphate buffer, $\mathrm{pH} \mathrm{7.0.} \mathrm{The}$ uricase reaction increased the sensitivity of the method, yielding another molecule of $\mathrm{H}_{2} \mathrm{O}_{2}$. Positive interference by the endogenous uric acid is avoided by measuring the test absorbance against a blank containing uricase.

\section{Procedure}

Substrate-buffer solution $(1.0 \mathrm{ml})$ and $50 \mu 1$ of guanase sample are mixed well and incubated 10 minutes at $37^{\circ} \mathrm{C}$ in a centrifuge tube. Add $1.0 \mathrm{ml}$ of reagent solution, vortex and immediately add $1.0 \mathrm{ml}$ of $\mathrm{HClO}_{4}(4 \mathrm{~mol} / \mathrm{l})$. Vortex again and centrifuge for 5 minutes at $3000 \mathrm{~min}^{-1}$. The absorbance of the clear supernatant is read at $410 \mathrm{~nm}$ against a blank (containing $1.0 \mathrm{ml}$ phosphate buffer, $5 \mu \mathrm{l}$ uricase, $50 \mu \mathrm{l}$ sample, $1.0 \mathrm{ml}$ reagent solution and $1.0 \mathrm{ml} \mathrm{HClO}_{4}$ ) prepared in the same way as the test. The final reaction product is stable for 360 minutes.

\section{Calculation}

The guanase catalytic activity was calculated as $A_{410 \mathrm{~nm}} \times 119.5$

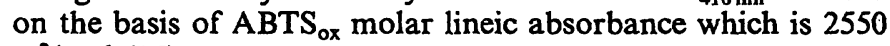
$\mathrm{m}^{2} / \mathrm{mol}(15)$.

\section{Statistics}

Statistical parameters such as the mean value $(\bar{x})$, standard deviation (SD), coefficients of variation (CV) and standard error $\left(s_{\bar{x}}\right)$ were calculated with standard statistical methods.

Regression analysis: the parameters $a$ (intercept with abscissa); $s_{a}$ (standard error of $a$ ), $t_{a}$ (Student's t-test for $s_{a}$ ), $b$ (slope of regression line), $s_{b}$ (standard error of $b$ ), and $t_{b}$ (Student's t-test for $s_{b}$ ) were calculated using the least-squares method (16). Our method was compared with the methods of Hue \& Free (4), Giusti (17), Wolthers et al. (7) and Ito et al. (18). The principle of the Hue \& Free method (4) is measurement of the decrease in absorbance at $245 \mathrm{~nm}$ due to guanine. For determination of guanase in the Giusti method (17), xanthine oxidase is used as the indicator enzyme. The reaction is followed by spectrophotometric measurements of resulting uric acid at $290 \mathrm{~nm}$. The method of Wolthers et al. (7) is based on the enzymatic conversion of ammonia by glutamate dehydrogenase in the presence of 2-oxoglutarate and NADH. The guanase assay by Ito et al. (18) is based on direct colorimetric determination of released ammonia using the phenol-nitroprusside reagent.

The ranges of reference values were calculated with a nonparametric method (16).

\section{Apparatus}

All measurements were performed with a Unicam SP 8000A spectrophotometer equipped with a Haake FS thermostat and
Weyfringe ADCP-2 printer. 


\section{Results}

\section{Linearity and sensitivity}

The linearity of the ABTS-method was examined with standard solutions of guanase prepared by dilution of commercially available guanase (spec. activity ca. $60 \mathrm{U} / \mathrm{g}$ ) with $66.7 \mathrm{mmol} / 1$ phosphate buffer, $\mathrm{pH} 7.0$ in the range 0 to $152 \mathrm{U} / 1$. Each solution was analysed in duplicate. By applying the correlation analysis to the results, the regression equation, $y_{x}=0,034+$ $120.033 \times\left(r=0.999, s_{y, x}=0.865, s_{a}=0,212, t_{a}=\right.$ 0.160 ) was calculated, which shows that the method is linear up to $149 \mathrm{U} / \mathrm{l}$. Good linearity in this range was confirmed by addition of different amounts of guanase to a serum pool. Regression analysis applied to the values obtained showed that the LambertBeer law was valid up to $152.5 \mathrm{U} / 1\left(\mathrm{y}_{\mathrm{x}}=0.028+\right.$ $0.0081 \mathrm{x}, \mathrm{s}_{\mathrm{x}, \mathrm{y}}=0.993, \mathrm{~s}_{\mathrm{a}}=0.045, \mathrm{t}_{\mathrm{a}}=0.623, \mathrm{p}>$ $0.6)$. The lowest catalytic activity of guanase that could still be assayed with good precision $(\mathrm{CV}=$ $5.4 \%$ ) was $0.11 \mathrm{U} / 1$ (fig. 1).

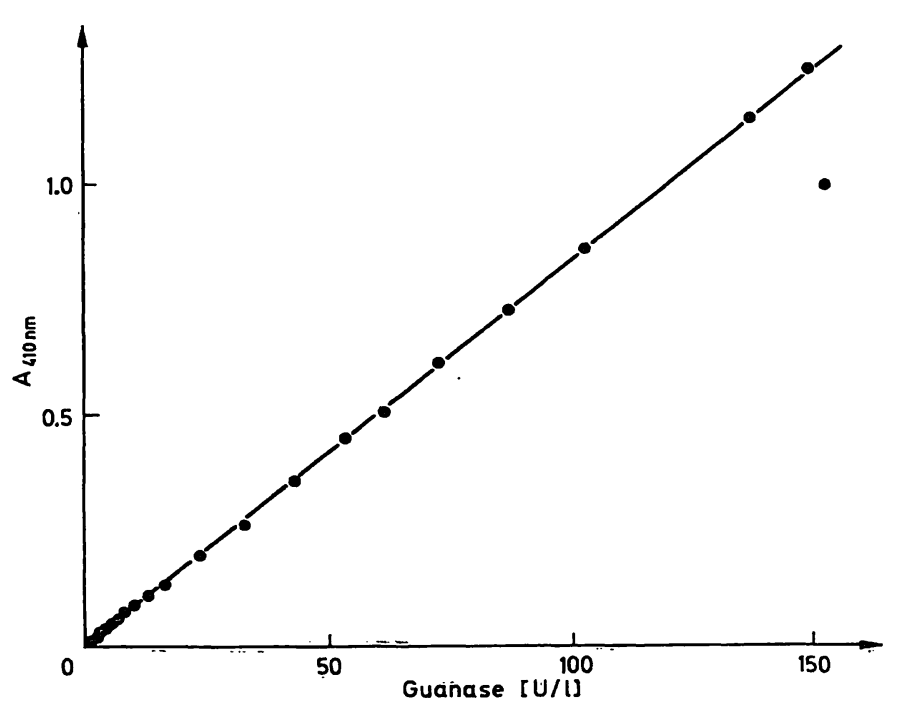

Fig. 1. Linearity of the ABTS-method: $y_{x}=0.034+$ $120.033 \mathrm{x}, \mathrm{r}=0.999, \mathrm{~s}_{\mathrm{y}, \mathrm{x}}=0.865, \mathrm{~s}_{\mathrm{a}}=0.212, \mathrm{t}_{\mathrm{a}}=$ $0.160, \mathrm{p}>0.05$.

\section{Recovery}

We investigated analytical recovery by adding guanase solutions to the serum pool to give total catalytic activities of guanase up to $152.45 \mathrm{U} / \mathrm{l}$. The results shown in table 1 are averages of duplicate assays and indicate the analytical recovery of guanase added to serum was quantitative $\left(y_{x}=5.850+0.999 x, r=\right.$ $0.001, \mathrm{~s}_{\mathrm{x}, \mathrm{y}}=8.493, \mathrm{~s}_{\mathrm{a}}=7.968, \mathrm{t}_{\mathrm{a}}=0.734, \mathrm{~s}_{\mathrm{b}}=$ $\left.0.076, \mathrm{t}_{\mathrm{b}}=0.551\right)$.
Tab. 1. Recovery of guanase estimated by ABTS-method.

\begin{tabular}{ccc}
\hline $\begin{array}{c}\text { Guanase added } \\
\mathrm{U} / 1\end{array}$ & $\begin{array}{l}\text { Activity } \\
\text { expected } \\
(\mathrm{U} / \mathrm{l})\end{array}$ & $\begin{array}{l}\text { Activity } \\
\text { observed } \\
(\mathrm{U} / \mathrm{l})\end{array}$ \\
\hline 0 & - & 12.4 \\
20.1 & 32.5 & 27.5 \\
40.1 & 52.5 & 55.5 \\
81.9 & 94.3 & 101.1 \\
112.5 & 124.9 & 120.8 \\
152.5 & 164.9 & 164.1 \\
\hline
\end{tabular}

\section{Precision}

The precision of the ABTS-method was examined with solutions of commercially obtained guanase, serum pools containing low, normal and pathological activity of guanase, and also with control sera Kontrologen L, LU and LP. All determination were repeated 12 times and calculated mean values, standard deviations and coefficients of variation are shown in table 2 .

Tab. 2. Precision of the ABTS-method $(n=12)$.

\begin{tabular}{|c|c|c|c|}
\hline Sample & $\begin{array}{l}\overline{\mathbf{x}} \\
(U / 1)\end{array}$ & $\begin{array}{l}\mathrm{SD} \\
(\mathrm{U} / \mathrm{I})\end{array}$ & $\begin{array}{l}\text { CV } \\
(\%)\end{array}$ \\
\hline \multicolumn{4}{|c|}{ Guanase solution } \\
\hline $\begin{array}{l}\text { low } \\
\text { medium } \\
\text { bigh }\end{array}$ & $\begin{array}{r}6.81 \\
25.16 \\
41.03\end{array}$ & $\begin{array}{l}0.45 \\
0.93 \\
0.81\end{array}$ & $\begin{array}{l}6.68 \\
3.71 \\
1.98\end{array}$ \\
\hline \multicolumn{4}{|l|}{ Serum pool } \\
\hline $\begin{array}{l}\text { low } \\
\text { normal } \\
\text { abnormal }\end{array}$ & $\begin{array}{r}6.87 \\
13.59 \\
23.00\end{array}$ & $\begin{array}{l}0.55 \\
0.71 \\
1.02\end{array}$ & $\begin{array}{l}8.11 \\
5.66 \\
4.44\end{array}$ \\
\hline \multicolumn{4}{|l|}{ Kontrollogen } \\
\hline $\begin{array}{l}\text { L } \\
\text { LU } \\
\text { LP }\end{array}$ & $\begin{array}{l}17.32 \\
28.85 \\
54.42\end{array}$ & $\begin{array}{l}1.16 \\
2.34 \\
3.02\end{array}$ & $\begin{array}{l}6.71 \\
8.13 \\
5.55\end{array}$ \\
\hline
\end{tabular}

Inter-method comparison

The accuracy of the ABTS-method was evaluated by comparison of the results obtained in normal and pathological serum samples with four other methods. Pathological serum samples were obtained from patients with acute and chronic pancreatitis, liver cirrhosis, hepatoma, chronic pyelonephritis and chronic glomerulonephritis. The correlations are presented in table 3 and figures 2 and 3 . Comparison with the methods of Hue \& Free (4), Giusti (17) and Ito et al. (18) gave good correlation. The ABTSmethod gave values that were 4 and $2 \mathrm{U} / \mathrm{l}$ higher than those obtained by the methods of Hue \& Free (4) and Ito et al. (18), respectively. In comparison to the 
Tab. 3. Regression analysis of serum guanase catalytic activity concentrations by the ABTS-method (y) vs. results by four other methods $(x)$.

\begin{tabular}{|c|c|c|c|c|c|c|c|c|}
\hline Method (ref.) & $\mathbf{n}$ & Regression line & $\mathbf{r}$ & $\mathbf{s}_{\mathbf{y}, x}$ & $\mathbf{s}_{\mathbf{a}}$ & $\mathbf{s}_{\mathbf{b}}$ & $t_{a}$ & $t_{b}$ \\
\hline $\begin{array}{l}\text { Hue \& Free (4) } \\
\text { Giusti (17) } \\
\text { Wolthers et al. (7) } \\
\text { Ito et al. (18) }\end{array}$ & $\begin{array}{l}47 \\
44 \\
45 \\
43\end{array}$ & $\begin{array}{l}y_{x}=4.214+1.052 x \\
y_{x}=6.652+0.887 x \\
y_{x}=11.893+0.895 x \\
y_{x}=1.831+1.003 x\end{array}$ & $\begin{array}{l}0.977 \\
0.952 \\
0.494 \\
0.969\end{array}$ & $\begin{array}{l}0.975 \\
1.454 \\
- \\
1.114\end{array}$ & $\begin{array}{l}0.380 \\
0.495 \\
- \\
0.536\end{array}$ & $\begin{array}{l}0.034 \\
0.043 \\
-: 1 \\
0.039\end{array}$ & $\begin{array}{c}11.062 \\
13.432 \\
-\quad \\
3.412\end{array}$ & $\begin{array}{l}1.544 \\
2.571 \\
- \\
0.097\end{array}$ \\
\hline
\end{tabular}

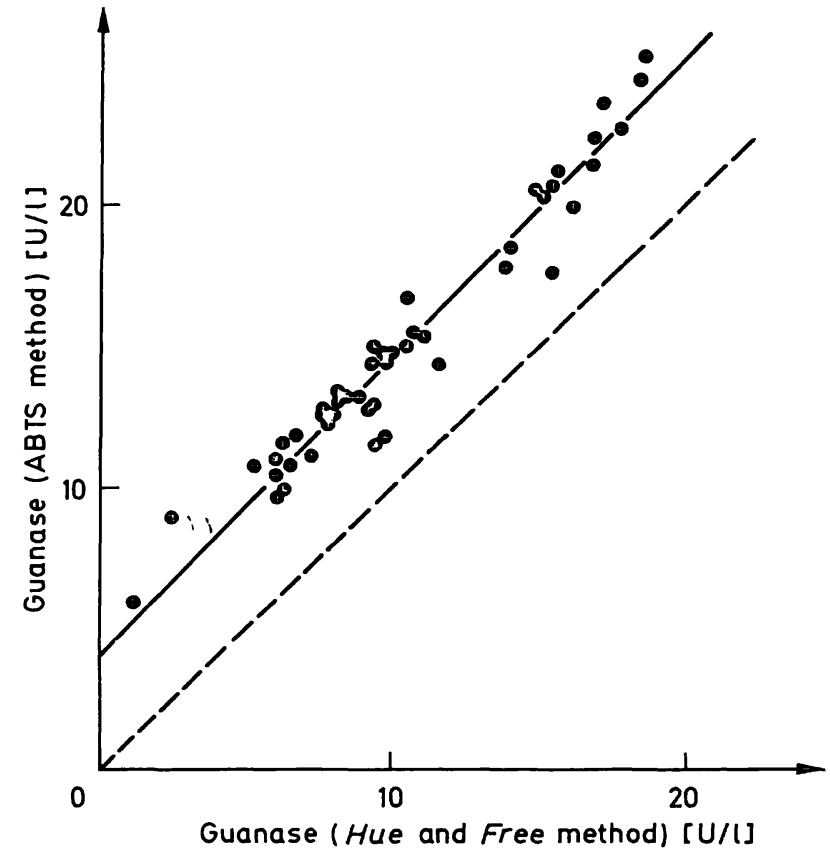

Fig. 2. Correlation of "results obtained by the ABTS-method $(y)$ and Hue and Free's method $(x)$ in 47 different human sera:

$\mathrm{y}_{\mathrm{x}}=4.214+1.052 \mathrm{x}, \mathrm{r}=0.977, \mathrm{~s}_{\mathrm{y}, \mathrm{x}}=0.975$.

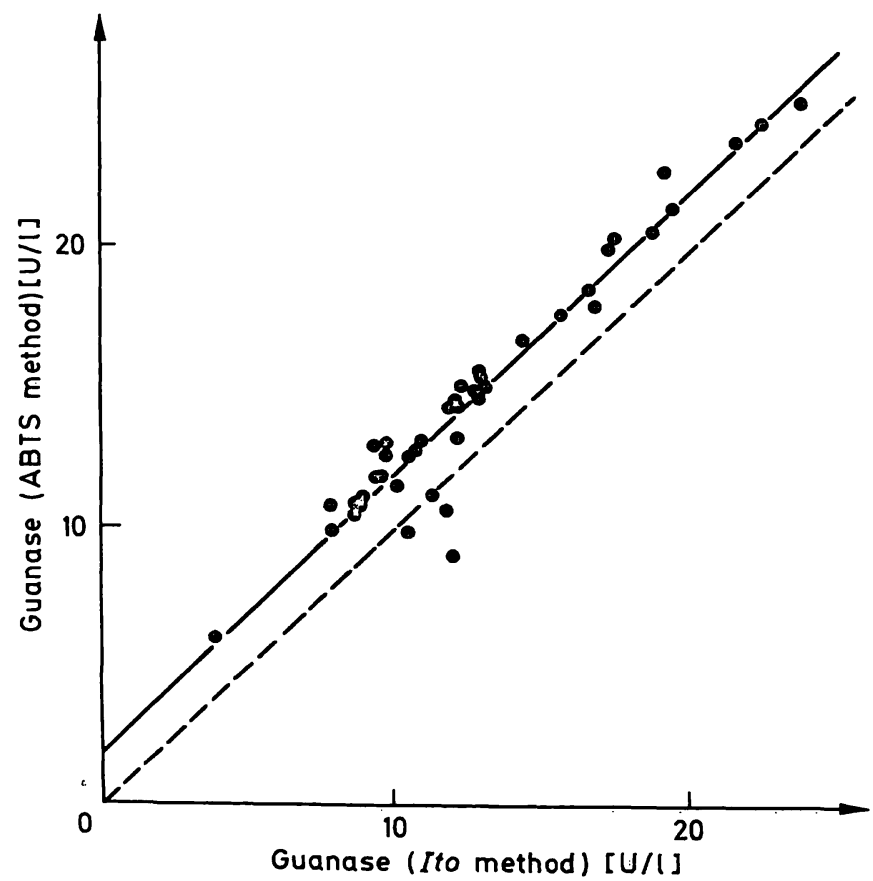

Fig. 3. Correlation of results obtained by the ABTS-method $(y)$ and Ito's method $(x)$ in 43 different human sera: $y_{x}=1.831+1.003 x, r=0.969, s_{y_{1} x}=1.114$.
Giusti method (17), the ABTS-method gave higher values up to an activity of $58.9 \mathrm{U} / 1$, and lower values above this value. No correlation was found with method of Wolthers et al. (7).

\section{Reference values}

Estimation of guanase catalytic activity by the ABTSmethod was performed on the sera of 86 healthy females and 173 males between 20 and 60 years of age. The mean values obtained wère $13.18 \mathrm{U} / 1$ (SD $=3.017 \mathrm{U} / \mathrm{l}, \mathrm{CV}=22.9 \%)$ and $13.95 \mathrm{U} / 1(\mathrm{SD}=$ $3.11 \mathrm{U} / 1, \mathrm{CV}=22.3 \%$ ), respectively. By Student's ttest $(t=1.893, p>0.05)$ the statistically significant difference was not proved and all results are observed together. Using a nonparametric method (16) the reference values for serum guanase activity in the range 2.93 to $23.92 \mathrm{U} / 1(\overline{\mathrm{x}}=13.57 \mathrm{U} / 1, \mathrm{SD}=3.04$ $\mathrm{U} / 1, \mathrm{CV}=22.4 \%$ ) were calculated (see fig. 4 ).

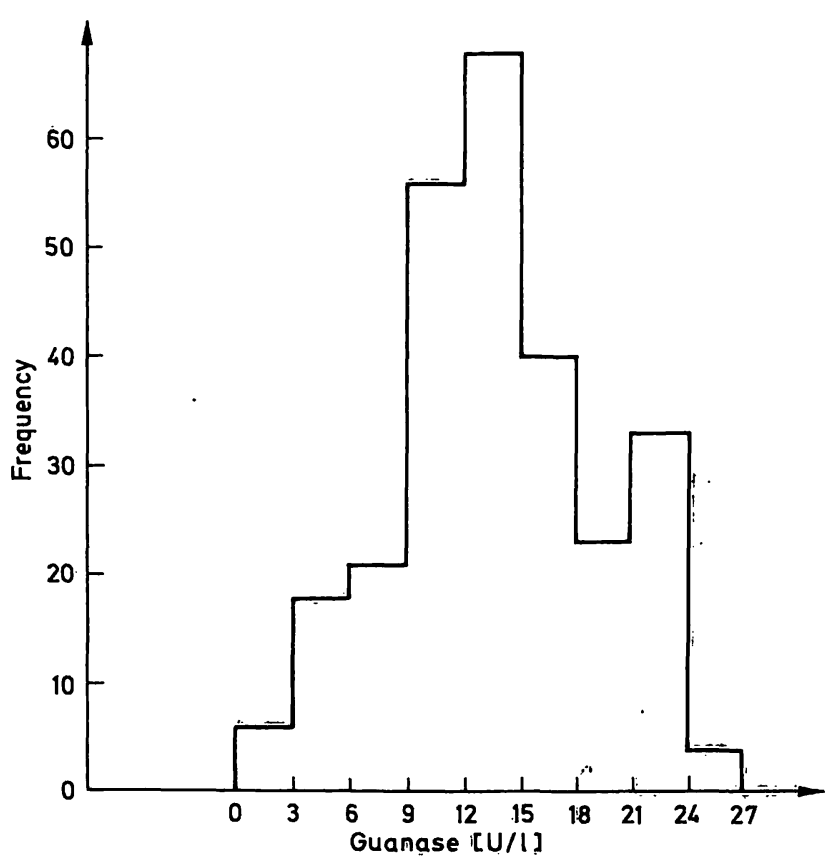

Fig. 4. Histogram of reference values for serum guanase determined by the ABTS-method in the sera of 259 healthy persons aged between 20 and 57 . 


\section{Pathological guanase activity}

By the new ABTS-method guanase activities were determined in sera obtained from 40 patients with different liver diseases, 33 patients with chronic kidney diseases, 40 drug-dependent patients and 46 alcoholics. The results are shown in figure 5 .

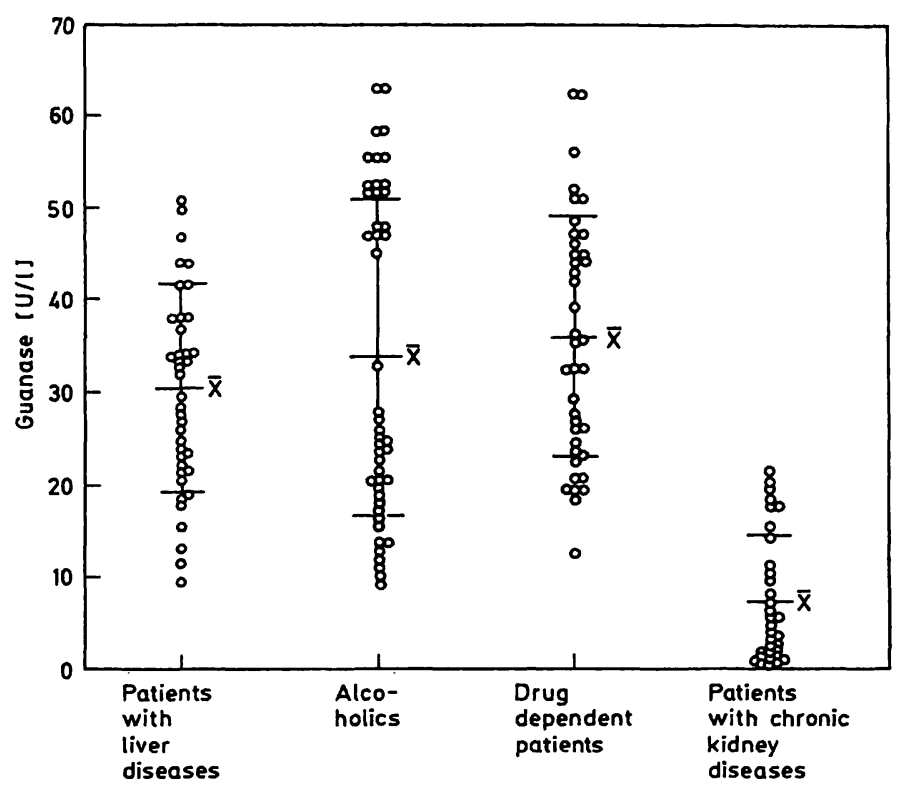

Fig. 5. Guanase activities determined in sera of patients with liver diseases, alcoholics, drug-dependent patients and patients with chronic kidney diseases.

\section{Discussion}

The present work describes a simple assay of guanase activity via $\mathrm{H}_{2} \mathrm{O}_{2}$ which is formed as a product of coupled reactions catalysed by xanthine oxidase and uricase. Xanthine formed in the hydrolytic guanase reaction is oxidized by xanthine oxidase to uric acid and $\mathrm{H}_{2} \mathrm{O}_{2}$. However, uric acid competes with ABTS for $\mathrm{H}_{2} \mathrm{O}_{2}$ in the presence of peroxidase $(19,20)$. For this reason, an auxillary reaction was introduced to decompose uric acid by uricase, and the indicator reagent was added after completion of the incubation. In addition, the uricase reaction increased the sensitivity of the method, yielding another molecule of $\mathrm{H}_{2} \mathrm{O}_{2}$. Also, this procedure enables the oxidation of uric acid present in serum samples. Positive interference by endogenous uric acid in serum is avoided by measuring the test absorbance against a sample blank containing uricase. If catalase (hydrogen-peroxide: hydrogen-peroxide oxidoreductase, EC 1.11.1.6) is present in the sample it can decompose the $\mathrm{H}_{2} \mathrm{O}_{2}$ formed, causing a decrease in the $\mathrm{ABTS}_{\text {ox }}$ absorbance which corresponds to guanase activity. This effect was avoided by addition of $9.52 \mathrm{mmol} / \mathrm{l}$ sodium azide.

The investigation presented here showed that the ABTS-method is sensitive, linear up to $152 \mathrm{U} / \mathrm{l}$ and precise (CV below $8.13 \%$ ). The accuracy of the method was investigated through recovery studies and by comparison with other known methods. The analytical recovery was quantitive in the range of linearity of method. The results obtained with the ABTS-method in different serum samples were compared with those obtained with four other methods based on different principles $(4,7,17,18)$. The best agreement was obtained with Ito's method (17). The ABTS-method did not correlate with Wolthers' $\operatorname{method}(7)(r=0,494)$.

As our method gives higher values than others, this method was more sensitive in the range of reference values. Normal catalytic activities of guanase determined by the ABTS-method in the sera of 259 healthy persons were 3 to 7 times higher than determined by other methods $(8-12)$. The reference interval for the ABTS-method is 2.93 to $23.92 \mathrm{U} / 1$. Caraway (5) and Hue \& Free (4) reported it to be $0-3 \mathrm{U} / 1$, Ellis et al. (6) up to $2.5 \mathrm{U} / 1$, Giusti (17) $0-7 \mathrm{U} / 1$, Wolthers et al. (7) $0.1-0.9 \mathrm{U} / 1$, Ito et al. (18) $0.4-2.0 \mathrm{U} / 1$, while Hishikawa \& Fukumoto (10) established a normal range from 0 to $1.02 \mathrm{U} / 1$.

Due to the high activities in liver and kidney, and the absence (or low level) in sera, determination of guanase activity might provide diagnostic information about kidney and liver lesions $(3,21)$. Increased serum activities in hepatic disorders have already been demonstrated in a number of publications ( 3 , 22, 23). Kuzmits et al. (24) stated that guanase is an extremely sensitive marker for liver cell damage. Furthermore, it was reported that guanase determinations are of diagnostic value in patients with renal diseases $(25,26)$, since reduced activities were found in patients with chronic kidney diseases (25).

To evaluate the reliability of results obtained by the ABTS-method, this method was applied to sera of patients with different liver and kidney disorders. The mean guanase activities determined by the ABTSmethod in sera of patients with different liver diseases $(\overline{\mathrm{x}}=30.20 \mathrm{U} / \mathrm{l}, \mathrm{SD}=10.73 \mathrm{U} / \mathrm{l})$, chronic alcoholics $(\overline{\mathrm{x}}=33.29 \mathrm{U} / \mathrm{l}, \mathrm{SD}=17.12 \mathrm{U} / \mathrm{l})$, and drug-dependent patients $(\overline{\mathrm{x}}=35.41 \mathrm{U} / \mathrm{l}, \mathrm{SD}=13.05 \mathrm{U} / \mathrm{l})$ were significantly higher then in normal persons. Patients with chronic kidney diseases had significantly lower activity $(\overline{\mathrm{x}}=7.22 \mathrm{U} / \mathrm{l}, \mathrm{SD}=6.97, \mathrm{t}=9.25, \mathrm{p}<$ 0.001 ). 
Finally, we conclude that the newly developed method for guanase determination, which uses ABTS as a chromogen, is specific, more sensitive than some other methods, and has good reproducibility. To evaluate the ABTS-method as a routine method for the differential diagnosis of liver and kidney diseases, serum guanase activities should be determined in various hepatic and kidney diseases and correlated with other enzymes used for the diagnosis of liver and kidney dysfunction.

\section{Acknowledgement}

This work was supported financially by a grant from the Scientific Community Institutions of SR Serbia.

\section{References}

1. Galanti, G., Russo, M., Nurdiello, S. \& Giusti, G. (1976) Enzyme 21, 342-348.

2. Levine, R., Hall, T. C. \& Harris, C. A. (1963) Cancer 16, $269-272$.

3. Knights, E. M., Whitehouse, J. S., Hue, A. C. \& Santos, C. L. (1965) J. Lab. Clin. Med. 65, 355-360.

4. Hue, A. A. \& Free, A. H. (1965) Clin. Chem. 11, 708-715.

5. Caraway, W. T. (1966) Clin. Chem. 12, 187-193.

6. Ellis, G., Spooner, R. J. \& Goldberg, D. M. (1973) Clin. Chim. Acta 47, 75-87.

7. Wolthers, B. G., Nusse, B. J., Bootsma, J. \& Groen, A. (1972) Clin. Chim. Acta 41, 223-230.

8. Kalckar, H. M. (1947) J. Biol. Chem. 167, 429-443.

9. Giusti, G., Galanti, B. \& Mancini, A. (1970) Enzymologia $38,373-382$.

10. Heinz, F., Reckel, S. \& Kalden, J. R. (1979) Enzyme 24, $247-254$.

11. Nishikawa, Y. \& Fukumoto, K. (1981) Clin. Chem. 27, $560-561$.

12. Gulberg, E. \& Christian, G. (1981) Fresenius Z. Anal. Chem. 305, 29-32.

13. Al-Khalidi, U. A.S., Aftimos, S., Musharrafieh, S. \& Khuri, N. N. (1970) Clin. Chim. Acta 29, 381-384.

14. van Bennekom, A. C., van Laarhoven, P. J., de Bruyn, M. M. H. C. \& Oei, L. T. (1978) J. Clin. Chem. Clin. Biochem. $16,145-248$.

15. Majkić, N. \& Berkeš, I. (1977) Clin. Chim. Acta 80 , $121-131$.

16. Bauer, E. L. (1971) Statistical Methods for Chemists, Academic Press, pp. $71-93$.

17. Giusti, G. (1974) In: Methods of Enzymatic Analysis (Bergmeyer, H. U. ed), Verlag Chemie, Academic Press (New York, San Francisco, London), p. 1086.

18. Ito, S., Takaoka, T., Mori, H. \& Teuro, A. (1981) Clin. Chim. Acta 115, 135-144.

19. Canellakis, S. E., Tuttle, L. A. \& Cohen, P. P. (1955) J. Biol. Chem. 213, 397-404.

20. Majkić-Singh, N., Stojanov, M., Spasić, S. \& Bệrkẹěs, I. (1981) Clin. Chim. Acta 116, 117 =123.

21. Whitehouse, J. L., Knights, E. M. jr., Santos, C. L. \& Hụe, A. C. (1964) Clin. Chem. 632-636.

22. Coodley, E. L. (1968) Am. J. Gastroenterol. 50, 55-60.

23. Nishikawa, Y., Fukumoto, K. \& Watanabe, F. (1984) Clin. Biochem. 17, 327-33).

24. Kuzmits, R., Seyfried, H., Wolf, A. \& Müller, M. M. (1980) Enzyme 148-152.

25. Kebejian, G. Y. \& Al-Khalidi, U. A. S. (1973) Europ. J. Clin. Invest. $3,41-43$.

26. Prodanov, K. \& Astrung, A. (1971) Clin. Chim. Acta 35, $445-448$.

Prof. Dr. N. Majkićc-Singh

Department of Biochemistry

Faculty of Pharmacy

Dr. Subotića 8, P. O." Box 146

YU-11000 Belgrade 